\title{
PENINGKATAN ORIENTASI PASAR BERBASIS DIGITAL DAN BERDAYA SAING PADA WIRAUSAHA MAHASISWA
}

\author{
Rizky Putra ${ }^{1)}$, Winda Ardiani ${ }^{2)}$ \\ Universitas Harapan Medan ${ }^{1)}$ \\ Universitas Harapan Medan ${ }^{2}$ \\ rizkyputrase@gmail.com \\ windaardiani.chan@gmail.com
}

\begin{abstract}
ABSTRAK
Banyak permasalahan dan kendala yang dihadapi wirausaha mahasiswa yang tak jarang menghambat dan mematikan usaha yang baru tumbuh itu. Mulai dari kekurangan sumber daya manusia dan penguasaan teknologi serta tidak adanya standarisasi dalam produksi. Serta yang paling sering terjadi yaitu rendahnya penjualan karena minimnya strategi pemasaran. Permsasalahan yang dihadapi mitra antara lain wirausaha belum memiliki strategi pasar yang tepat dalam memasarkan produk. Wirausaha belum memiliki strategi pemasaran secara digital dengan memanfaatkan media internet secara efektif. Solusi yang dilakukan antara lain workshop mengenai strategi pemasaran yang lebih integrative dan workshop penyusunan media promosi berbasis digital.Kegiatan telah terlaksana sesuai dengan rencana yang sudah ditentukan yaitu workshop penyusunan strategi pemasaran dan workshop penyusunana konten pemasaran digital yang diikuti oleh 5 mitra yang merupakan mahasiswa Universitas Harapan Medan yang memiliki usaha. Terjadi peningkatan pengetahuan dan ketrampilan mitra setelah mengikuti workshop yang dilaksanakan sebagai bagian dari kegiatan pengabdian masyrakat ini.
\end{abstract}

Kata kunci :Wirausaha mahasiswa, Pemasaran, Digital

\begin{abstract}
There are many problems and obstacles faced by student entrepreneurs who often inhibit and turn off the new business. Starting from a lack of human resources and mastery of technology and the absence of standardization in production. And the most common is the low sales due to the lack of marketing strategies. The problems faced by partners include entrepreneurs who do not have the right market strategy in marketing their products. Entrepreneurship does not yet have a digital marketing strategy by using internet media effectively. The solutions include workshops on more integrative marketing strategies and workshops on the preparation of digital-based promotional media. The activities have been carried out in accordance with the predetermined plan, namely a workshop on the preparation of a marketing strategy and a workshop on the preparation of digital marketing content which was attended by 5 partners who were students of Harapan Medan University who owned a business. There has been an increase in the knowledge and skills of partners after attending workshops that were carried out as part of the community service activities.
\end{abstract}

Key Words: Student Entrepreneurship, Marketing, Digital

\section{PENDAHULUAN}

Wirausaha mahasiswa merupakan komponen penting penting di masyarakat. Perkembangan wirausaha pada mahasiswa menarik perhatian yang lebih serius dari berbagai kalangan baik pemerintah ataupun masyarakat umum, hal ini tidak terlepas dari perannya dalam penyerapan tenaga kerja, sumbangan pendapatan nasional (GDP) dan ketahanan UKM terhadap berbagai gejolak. Peran wirausaha dalam perekonomian nasional dinilai sangat strategis. Sektor ini juga dianggap sebagai penyelamat krisis yang dihadapi Indonesia sejak tahun 1997 karena fleksibilitasnya dalam menyiasati perubahan dan kemampuannya menyerap tenaga kerja sehingga 
mampu mengurangi tingkat pengangguran dan kemiskinan.

Banyak yang menunjukkan

bahwa wirausaha mahasiswa memiliki peran yang vital dalam mendukung pengembangan profesi pasca menjadi alumni perguruan tinggi diantaranya, pertama menyerap banyak tenaga kerja, melalui modal yang sedikit bisa membangun usaha kecil, teknologi yang digunakan sangat sederhana sehingga bersifat padat karya, yang memerlukan banyak tenaga kerja. Kedua terjadinya pemerataan dalam distribusi pembangunan daerah. Wirausaha mahasiswa yang berkembang dapat mendorong terjadi pemerataan khususnya distribusi pendapatan, pemerataan pembangunan, akan mengurangi diskriminasi antara kota dan desa. Ketiga, pemerataan dalam distribusi, pendapatan, pengembangan wirausaha mahasiswa yang melibatkan banyak tenaga kerja pada akhirnya akan mempertinggi daya beli

Studi yang dilakukan oleh International Labour Organization (ILO) seperti dikemukakan dalam Sethuraman (1993), dijelaskan bahwa aktivitas-aktivitas wirausaha pemula tidak terbatas pada pekerjaan-pekerjaan tertentu, tetapi bahkan juga meliputi berbagai aktivitas ekonomi yang antara lain ditandai dengan: mudah untuk dimasuki, bersandar pada sumberdaya lokal, usaha milik sendiri, opersinya dalam skala kecil, padat karya dan teknologinya bersifat adaptif, ketrampilan dapat diperoleh di luar sistem sekolah formal, dan tidak terkena langsung oleh regulasi dan pasarnya bersifat kompetitif. Studi yang dilakukan ILO ini menyebutkan sektor wirausaha pemula punya ciri: ukuran usaha kecil, kepemilikan keluarga, intensif tenaga kerja, status usaha individu, tanpa promosi, dan tidak ada hambatan masuk.

Pelaku usaha pemula juga menghadapi tantangan yang sangat berat terkait dengan pengembangan usahanya.Kendala serta tantangan tersebut datang seiring dengan dibukanya skemaperdagangan bebas ASEAN-China Free Trade Agreement (ACFTA) sejak awal tahun 2010 yang lalu. Kemudian di penghujung tahun 2015 masyarakat kita menghadapi perdagangan bebas Asia Tenggara atau yang dikenal dengan MEA 2015

Sayangnya tidak selamanya pelaku wirausaha ini dapat terus berkembang menjadi besar tanpa pendampingan.

Banyak permasalahan dan kendala yang dihadapi wirausaha mahasiswa yang tak jarang menghambat dan mematikan usaha yang baru tumbuh itu. Mulai dari kekurangan sumber daya manusia dan penguasaan teknologi serta tidak adanya standarisasi dalam produksi. Serta yang paling sering terjadi yaitu rendahnya penjualan karena minimnya strategi pemasaran

Berdasarkan hasil pengamatan awal terhadap wirausaha mahasiswa yang membentuk usaha kecil dan menengah terlihat bahwa mayoritas wirausaha memiliki usaha kuliner dan fashion. Untuk produk kuliner bila dilihat secara fisik banyak sekali kekurangan yang dmiliki oleh pelaku usaha, secara khusus adalah kemasan. Pelaku usaha tidak memiliki kemasan pembungkus yang i-catching, terkesan asal-asalan, selain itu tidak mencantumkan standar-stanar dalam pembuatan kemasan (merek, 
kandungan, serta tanggal kadaluarsa), selain itu tidak memiliki desain yang menarik pembeli. Bila diperhatikan konteks kesehatannya juga masih belum baik, sebab menggunakan plastik yang gampang rusak bila terkena panas. Tentunya hal ini sangat tidak baik bila dilanjutkan, oleh karena itu butuh penanganan khusus.

Kemudian aspek lainnya yang masih menjadi masalah adalah belum adanya strategi khusus untuk mengembangkan pasar. Hal ini ditandai dengan belum adanya pemetaan pasar yang tepat, serta pemanfaatan strategi berbasis digital juga masih belum optimal, padahal strategi digital merupakan salah satu strategi yang cukup murah untuk digunakan sebagai salah satu media pemasaran.

Oleh karena itu perlu peningkatan wirausaha mahasiswa secara khusus pada peningkatan aspek pemasaran. Hal ini dilakukan karena aspek inilah yang menjadi masalah paling vital dalam mengembangkan bisnis mahasiswa

\section{METODE PELAKSANAAN}

Saat ini permasalahan yang dihadapi wirausaha sebagai mitra antara lain ,

1. Wirausaha /mitra yang tidak memilikistrategi pemasaran yang integrative

2. Wirausaha/mitra belum memiliki media promosi digital yang efektif

Oleh sebab itu diperlukan sebuah upaya produktif dan kontinyu dalam mengatasi permasalahan tersebut dengan kegiatan Peningkatan Orientasi Pasar Berbasis Digital danBerdaya Saing Pada
Wirausaha Mahasiswa. Adapun pendekatan yang akan digunakan dalam kegiatan ini dapat dilihat pada matriks berikut ini,

Tabel 1. Pendekatan Dalam Kegiatan

\begin{tabular}{|c|c|c|}
\hline No & $\begin{array}{c}\text { Jenis } \\
\text { kegiatan }\end{array}$ & Metode/pendekatan \\
\hline 1 & $\begin{array}{l}\text { Workshop } \\
\text { mengenai } \\
\text { strategi } \\
\text { pemasaran } \\
\text { yang lebih } \\
\text { integratif }\end{array}$ & $\begin{array}{l}\text { 1. Workshop akan } \\
\text { dilaksanakan } 1 \text { hari } \\
\text { dengan metode } \\
\text { ceramah, diskusi } \\
\text { simulasi, dan latihan } \\
\text { dengan rincian materi } \\
\text { 2. Di akhir sesi mitra } \\
\text { sudah memiliki strategi } \\
\text { pemasaran yang lebih } \\
\text { integratif }\end{array}$ \\
\hline 2 & $\begin{array}{l}\text { Workshop } \\
\text { penyusunan } \\
\text { media } \\
\text { promosi } \\
\text { berbasis } \\
\text { digital }\end{array}$ & $\begin{array}{l}\text { 1. Tim akan membantu } \\
\text { mitra menyusun } \\
\text { media yang efektif } \\
\text { untuk pemasaran } \\
\text { produk mitra } \\
\text { 2. Tim akan } \\
\text { mengajarkan secara } \\
\text { teknis proses serta } \\
\text { tips dalam } \\
\text { pembuatan media } \\
\text { promosi digital }\end{array}$ \\
\hline \multicolumn{3}{|c|}{ Sumber: Data diolah, 2018} \\
\hline
\end{tabular}

\section{a. Workshop mengenai strategi pemasaran yang lebih integratif}

Kegiatan ini dilakukan selama satu hari dari pukul 09.00 s.d 16.00 WIB, Kegiatan ini dilakukan dengan metode ceramah, diskusi, simulasi yang melibatkan peran aktif semua peserta. Materi-materi yang akan disampaikan antara lain

a. Prinsip dasar pemasaran

b. Riset pasar

c. Validasi pasar

d. Positioning dan Targeting

Kegiatan akan dilakukan di rumah warga secara partisipatif, sehingga mitra merasa enjoy dalam 
mengikuti workshop. Pada akhir sesi, mitra diharapkan mengetahui dan memiliki strategi pasar yang lebih baik

\section{b. Workshop penyusunan media promosi berbasis digital}

Mitra akan mendapatkan bantuan teknis penyusunan media digital dalam rangka promosi produk, secara spesifik antara lain :

\section{a. Pemanfaatan media sosial}

b. Tips menggunakan facebook ads

Tabel 2. Permasalahan dan Solusi Kegiatan

\begin{tabular}{|c|l|l|l|l|}
\hline No & Masalah & Solusi Kegiatan & Luaran & $\begin{array}{l}\text { Partisipasi } \\
\text { Masyarakat }\end{array}$ \\
\hline 1 & $\begin{array}{l}\text { Wirausaha /mitra yang } \\
\text { tidak memilikistrategi } \\
\text { pemasaran yang } \\
\text { integrative }\end{array}$ & $\begin{array}{l}\text { Workshop mengenai } \\
\text { strategi pemasaran } \\
\text { yang lebih integratif }\end{array}$ & $\begin{array}{l}\text { Adanya } \\
\text { peningkatan } \\
\text { pengetahuan dan } \\
\text { ketrampilan mitra }\end{array}$ & $\begin{array}{l}\text { Mitra menyusun } \\
\text { sendiri strategi } \\
\text { pemasaran bisnis } \\
\text { mmereka }\end{array}$ \\
\hline 2 & $\begin{array}{l}\text { Wirausaha/mitra belum } \\
\text { memiliki media promosi } \\
\text { digital yang efektif }\end{array}$ & $\begin{array}{l}\text { Melatih mitra } \\
\text { melalui Workshop } \\
\text { penyusunan media } \\
\text { promosi berbasis } \\
\text { digital }\end{array}$ & $\begin{array}{l}\text { Adanya } \\
\text { peningkatan } \\
\text { pengetahuan dan } \\
\text { ketrampilan mitra }\end{array}$ & $\begin{array}{l}\text { Mitra membuat } \\
\text { sendiri konten } \\
\text { digital serta media } \\
\text { digital yang } \\
\text { digunakan untuk } \\
\text { promosi produk. }\end{array}$ \\
\hline
\end{tabular}

Sumber: Data diolah, 2018

\section{HASIL DAN PEMBAHASAN}

Berdasarkan rencana kegiatan yang sudah disusun sebelumnya, maka hasil atau realisasi kegiatan yang dilaksanakan dijelaskan sebagai berikut:

\section{Workshop mengenai strategi pemasaran yang lebih integratif}

Kegiatan ini sudah dilaksanakan pada tanggal 07 Mei 2019 di Kampus Universitas Harapan Medan pada pukul 09.00 s.d 16.00 WIB. Kegiatan ini diikutioleh 5 mahasiswa yang memiliki usaha dan diikuti pula oleh staf/rekan kerja yang sama-sama menjalankan bisnis.

Kegiatan dilakukan dengan metode ceramah, diskusi, dan

\section{c. Tips promosi melalui instagram \\ d. Tips menyusun konten digital}

Pada proses pemberian mitra akan diajarkan cara mengoperasionalkan dan menyusun konten promosi produk mereka. Kemudian secara khusus hubungan permasalahan dan kegiatan ini dapat dilihat pada tabel berikut ini: simulasi yang melibatkan peran aktif semua peserta. Materi-materi yang akan disampaikan sesuai dengan yang direncanakan yaitu:
a. Prinsip
dasar pemasaran
b. Riset pasar
c. Validasi pasar
d. Positioning dan Targeting

Kegiatan dilakukan di kampus Universitas Harapan Medan secara partisipatif, sehingga mitra merasa enjoy dalam mengikuti workshop. Pada akhir sesi, mitra sudah memiliki rancangan strategi pemasaran yang sudah dikembangkan sesuai dengan bisnis masing-masing. 
Kemudian berdasarkan hasil perhitungan skor sebelum dan sesudah pelatihan dapat diketahui pada gambar berikut ini,

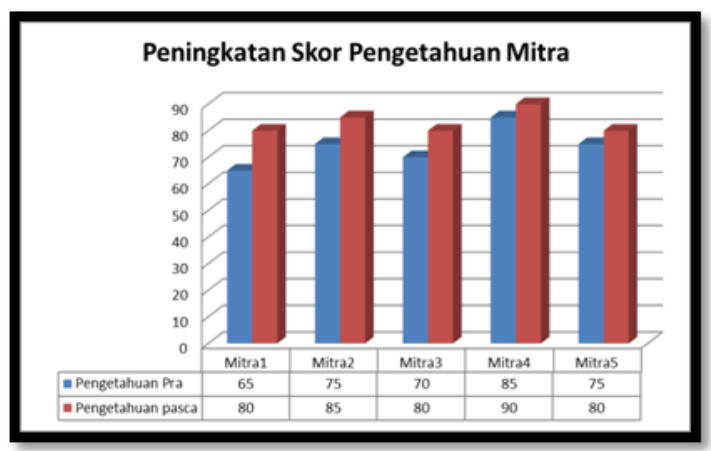

Gambar 1.

Peningkatan Skor Pengetahuan Mitra Sumber: Data diolah, 2018

\section{Kemudian secara statistik dapat diketahui bahwa terjadi peningkatan pengetahuan mitra sebelum dan sesudah pelatihan, seperti terlihat pada tabel berikut ini,}

\section{Tabel 3. Uji Statistik}

Test Statistics

\begin{tabular}{|l|r|}
\hline & Pasca - Pra \\
\hline Z & $-2,041^{\mathrm{a}}$ \\
Asymp. Sig. (2-tailed) &, 041 \\
\hline
\end{tabular}

a. Based on negative ranks.

b. Wilcoxon Signed Ranks Test

Sumber: Data diolah, 2018

Tabel menunjukkan bahwa nilai signifikansi sebesar 0,041 , hal ini menunjukkan bahwa workshop secara signifikan berhasil meningkatkan pengetahuan mitra sebagai peserta workshop.

Berikut Ini adalah dokumentasi kegiatan yang dilakukan pada workshop pertama dalam kegiatan pengabdian masyarakat ini,

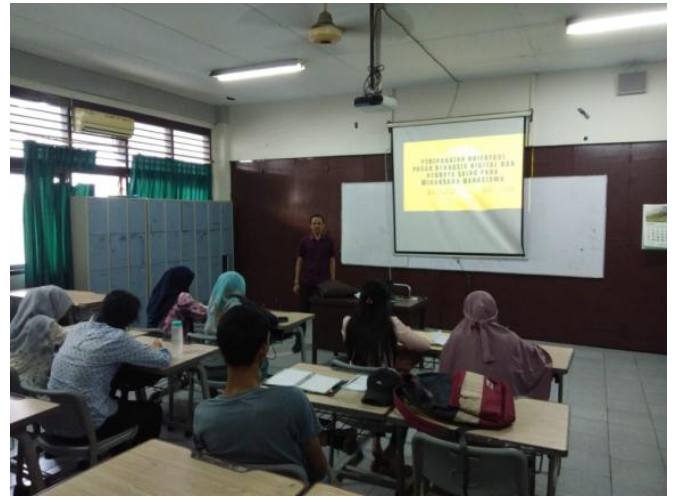

Ketua tim pengabdian masyrakat memberikan paparan materi terkait strategi pemasaran pada mitra yang berlokasi di Kampus Universitas Harapan Medan.

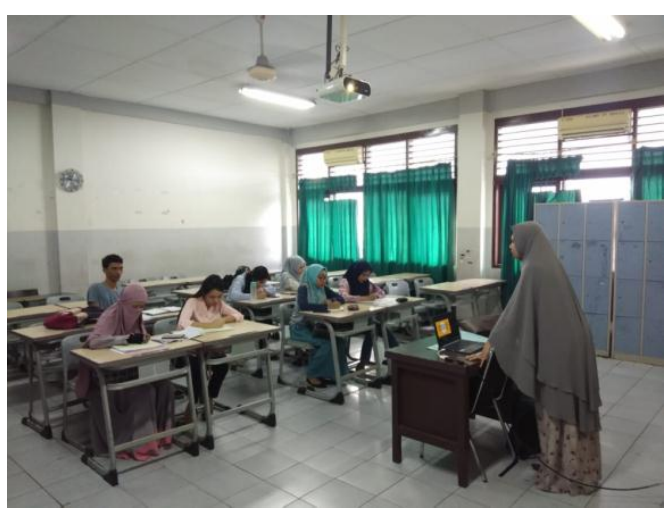

Anggota tim pengabdian masyarakat memberikan materi sambungan dalam pengembangan strategi pemasran produk mitra.

Secara proses kegiatan workshop pertama berjalan lancar sesuai dengan rencana, kemudian secara hasil sesuai dengan target yang sudah ditentukan yaitu terjadi peningkatan pengetahuan mitra dan mitra memiliki rencana strategi pemasaran yang dapat membantu meningkatkan kualitas bisnis mitra. 


\section{Workshop penyusunan media promosi berbasis digital}

Kegiatan ini sudah dilaksanakan pada tanggal 20 Juni 2019 di Kampus Universitas Harapan Medan pada pukul 09.00 s.d 15.00 WIB. Kegiatan ini diikuti oleh 5 mahasiswa yang sama yang mengikuti workshop sebelumnya dan memiliki usaha serta diikuti pula oleh staf/rekan kerja yang sama-sama menjalankan bisnis.

Kegiatan dilakukan dengan metode ceramah, dan praktik yang melibatkan peran aktif semua peserta untuk menyusun sendiri konten digital bisnis mereka. Materi-materi yang akan disampaikan sesuai dengan yang direncanakan yaitu:

a. Pemanfaatan media sosial

b. Tips menggunakan facebook ads

c. Tips promosi melalui instgaram

d. Tips menyusun konten digital Kegiatan dilakukan di kampus Universitas Harapan Medan secara partisipatif agar mitra dapat mengikuti workshop secara aktif dan tidak kaku. Pada akhir sesi, mitra sudah memiliki konten media sosial yang sudah dikembangkan sesuai dengan bisnis masing-masing.

Tim pengabdian mengukur secara observatif kemampuan mitra dalam menyusun konten promosi digital melalui berbagai media yaitu (Facebook, email, Twitter, Instagram dan Whats app). Sehingga berdasarkan kemampuan menyusun konten berdasarkan aplikasi tersebut maka secara akumulatif dapat di ukur ketrampilan pemanfaatan media digital dalam promosi produk mitra pada gambar berikut ini,

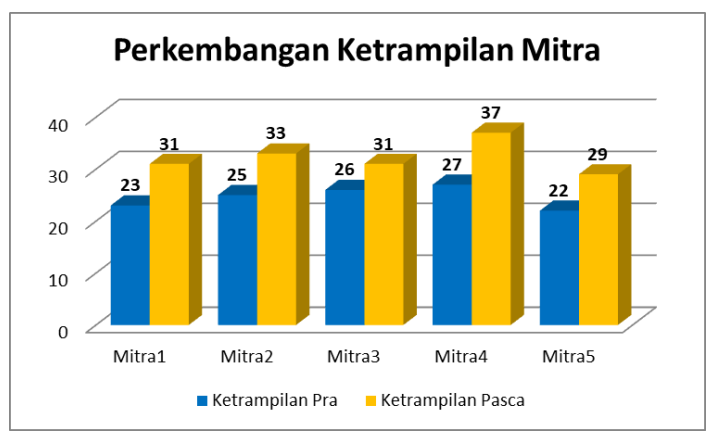

Gambar 2.

Perkembangan Keterampilan Mitra Sumber: Data diolah, 2018

Hasil menunjukkan bahwa ada peningkatan skor ketrampilan yang diperoleh mitra sebelum mengikuti workshop dan sesudah mengikuti workshop yang dilaksanakan tim pengabdian. Kemudian secara statistik dapat dilihat pada tabel berikut ini,

Tabel 3. Uji Statistik

Test Statistics ${ }^{\text {b }}$

\begin{tabular}{l|r|}
\hline & Ketpas - Ketpra \\
\hline Z & $-2,032^{a}$ \\
Asymp. Sig. (2-tailed) &, 042 \\
\hline a. Based on negative ranks. \\
b. Wilcoxon Signed Ranks Test \\
Sumber: Data diolah, 2018
\end{tabular}

Hasil uji wilcoxon menunjukkan bahwa pada taraf signifikansi 0,05 terbukti bahwa nilai signifikansi $0,042<0,05$. Hal ini menunjukkan bahwa workshop 2 secara signifikan berhasil meningkatkan ketrampilan mitra sebagai peserta workshop. Pemanfaatan media sosial merupakan salah satu upaya dalam meningkatkan penjualan produk bisnis, beberapa media sosial yang digunakan antara lain Instagram dan facebook.

Hal ini sesuai dengan penelitian Ramadhan (2017) yang membuktikan bahwa pemasaran yang dilakukan Mr.Creampuff lewat instagram merupakan cara yang 
efektif dan efisien dalam meningkatkan penjualannya dan prosesnya tidak begitu lama. Begitu juga dengan penelitian Gumilar (2015) di Bandung yang memperlihatkan bahwa seluruh responden menggunakan media sosial dan instagram merupakan media sosial yang paling banyak digunakan dan dinilai paling efektif oleh Pengelola Industri Fashion di Kota Bandung.

Dalam kegiatan ini mitra masih tergolong kurang terampil dalam memanfaatkan instagram sebagai media promosi, terindikasi dari skor penggunaan instagram yang masih rendah dibanding media yang lainnya. Oleh karena itu perlu peningkatan skill scara khusus penggunaan instagram saja sebagai media promosi.

$\begin{array}{ccr}\text { Berikut } & \text { Ini } & \text { adalah } \\ \text { dokumentasi } & \text { kegiatan } & \text { yang }\end{array}$ dilakukan pada workshop pertama dalam kegiatan pengabdian masyrakat ini,

Secara proses kegiatan workshop kedua berjalan lancar sesuai dengan rencana, kemudian secara hasil sesuai dengan target yang sudah ditentukan yaitu terjadi peningkatan pengetahuan mitra dan mitra memiliki rencana strategi pemasaran yang dapat membantu meningkatkan kualitas bisnis mitra.

\section{KESIMPULAN DAN SARAN Kesimpulan}

Adapun kesimpulan dari kegiatan pengabdian ini antara lain,

1. Kegiatan telah terlaksana sesuai dengan rencana yang sudah ditentukan yaitu workshop penyusunan strategi pemasaran dan workshop penyusunana konten pemasaran digital yang diikuti oleh 5 mitra yang merupakan mahasiswa Universitas Harapan Medan yang memiliki usaha

2. Dengan nilai signifikansi sebesar $0,041<0,05$ hal ini menunjukkan bahwa workshop 1 tentang strategi pemasaran secara signifikan berhasil meningkatkan pengetahuan mitra sebagai peserta workshop

3. Dengan nilai signifikansi sebesar $0,042<0,05$ hal ini menunjukkan bahwa workshop 2 tentang penyusunan konten digital secara signifikan berhasil meningkatkan ketrampilan mitra sebagai peserta workshop

\section{Saran}

Adapun saran dari kegiatan ini antara lain,

1. Kegiatan pengabdian ini sebaiknya dibuat untuk sasaran mitra yang lebih banyak agar dampak yang ditimbulkan juga semakin besar bagi universitas Harapan Medan secara khususnya

2. Perlu pendalaman secara khusus untuk pemanfaatan media instagram dan twitter dalam mendukung promosi produk mitra, sebab dari seluruh media yang digunakan kedua media ini masih tergolong kurang terampil dalam memanfaatkannya sebagai media promosi produk

\section{REFERENSI}

Gumilar, Gumgum. (2015). Pemanfaatan Instagram Sebagai Sarana Promosi Oleh Pengelola Industri Kreatif Fashion Di Kota Bandung. Jurnal Ilmu Politik dan Komunikasi, V( 2), 77-84. 
Purnomo Setyawan. (2009).

Menumbuhkan Kebiasaan

Menyusun Laporan

Keuangan pada Usaha Kecil

dan Menengah. Jurnal

Bisnis dan Usahawan. II(

7), 181-194.

Ramadhan, Fadli Harisa. (2017).

Pemanfaatan Media Sosial

Instagram

Akun

@ Mr.Creampuff Sebagai

Promosi Dalam

Meningkatkan Penjualan.

JOM FISIP, 4 (2), 1-15.

Sethuraman., S.U., (1993), The

Urban Informal Sector in
Developing Countries. Jenewa: International Labor Organization. 